\title{
Nanocomposite $\mathrm{LiFePO}_{4} \cdot \mathrm{Li}_{3} \mathrm{~V}_{2}\left(\mathrm{PO}_{4}\right)_{3} / \mathrm{C}$ synthesized by freeze-drying assisted sol-gel method and its magnetic and electrochemical properties
}

\author{
Liying Liu ${ }^{1,2}$, Wenxue Xiao ${ }^{1}$, Jianfeng Guo ${ }^{1}$, Yanyan $\mathrm{Cui}^{1}, \mathrm{Xi} \mathrm{Ke}^{1}$, Weitong $\mathrm{Cai}^{1}$, Jun $\mathrm{Liu}^{1}$, \\ Yiming Chen ${ }^{1}$, Zhicong Shi ${ }^{1 *}$ and Shulei Chou ${ }^{2 *}$
}

\begin{abstract}
Nano-sized LiFePO $\mathrm{O}_{4} \cdot \mathrm{Li}_{3} \mathrm{~V}_{2}\left(\mathrm{PO}_{4}\right)_{3} / \mathrm{C}$ was synthesized via a sol-gel route combining with freeze-drying. $\mathrm{X}$-ray diffraction results show that this composite mainly consists of olivine $\mathrm{LiFePO}_{4}$ and monoclinic $\mathrm{Li}_{3} \mathrm{~V}_{2}\left(\mathrm{PO}_{4}\right)_{3}$ phases with small amounts of $\mathrm{V}$-doped $\mathrm{LiFePO}_{4}$ and $\mathrm{Fe}$-doped $\mathrm{Li}_{3} \mathrm{~V}_{2}\left(\mathrm{PO}_{4}\right)_{3}$. The magnetic properties of $\mathrm{LiFePO}_{4} \cdot \mathrm{Li}_{3} \mathrm{~V}_{2}\left(\mathrm{PO}_{4}\right)_{3} / \mathrm{C}$ are significantly different from $\mathrm{LiFePO}_{4} / \mathrm{C}$. Trace quantities of ferromagnetic impurities and $\mathrm{Fe}_{2} \mathrm{P}$ are verified in $\mathrm{LiFePO}_{4} / \mathrm{C}$ and $\mathrm{LiFePO}_{4} \cdot \mathrm{Li}_{3} \mathrm{~V}_{2}\left(\mathrm{PO}_{4}\right)_{3} / \mathrm{C}$ by magnetic tests, respectively. LiFe$\mathrm{PO}_{4} \cdot \mathrm{Li}_{3} \mathrm{~V}_{2}\left(\mathrm{PO}_{4}\right)_{3} / \mathrm{C}$ possesses relatively better rate capacities and cyclic stabilities, especially at high charge-discharge rates. The initial discharge capacities are 136.4 and $130.0 \mathrm{~mA} \mathrm{~h} \mathrm{~g}^{-1}$, and the capacity retentions are more than $98 \%$ after 100 cycles at $2 \mathrm{C}$ and $5 \mathrm{C}$, respectively, remarkably better than those of $\mathrm{LiFePO}_{4} / \mathrm{C}$. The excellent electrochemical performances are ascribed to the mutual doping of $\mathrm{V}^{3+}$ and $\mathrm{Fe}^{2+}$, complementary advantages of $\mathrm{LiFePO}_{4}$ and $\mathrm{Li}_{3} \mathrm{~V}_{2}\left(\mathrm{PO}_{4}\right)_{3}$ phases, the residual high-ordered carbon and $\mathrm{Fe}_{2} \mathrm{P}$ with outstanding electric conductivity in the nanocomposite.
\end{abstract}

Keywords: lithium ion battery, cathode material, lithium iron phosphate, lithium vanadium phosphate, magnetic property

\section{INTRODUCTION}

In order to solve the energy and environmental problems simultaneously, electric vehicles (EVs), hybrid electric vehicles (HEVs) and large-scale energy storage devices have attracted incredible interests all over the world. These also put forward high requirements on capacity, cycle life and safety for lithium ion batteries (LIB) [1,2]. Cathode materials are still the key issues not only to improve electrochemical properties but also to reduce total cost of LIB. Among all potential cathode materials, polyanion phosphate material $\mathrm{LiFePO}_{4}$ (LFP) has been commercialized and applied successfully in small power tools. However, it cannot meet the demands raised by EVs and HEVs because of poor intrinsic electronic and ionic conductivities [3,4]. Several methods have been widely used to eliminate these obstacles, such as conductive layer coating (usually carbon) [5-7], nanoparticles controlling [8-10] and metal cations doping [11-13]. In fact, these modification methods are often combined to achieve perfect energy and power densities. However, LFP is still not so satisfactory and hence more effective modifications are needed to be sought.

Recently, LFP and $\mathrm{Li}_{3} \mathrm{~V}_{2}\left(\mathrm{PO}_{4}\right)_{3}$ (LVP) composite ( $x \mathrm{Li}$ $\mathrm{FePO}_{4} \cdot y \mathrm{Li}_{3} \mathrm{~V}_{2}\left(\mathrm{PO}_{4}\right)_{3} / \mathrm{C}$, abbreviated as $\left.x \mathrm{LFP} \cdot y \mathrm{LVP} / \mathrm{C}\right)$ has drawn more attention. LVP is a relatively fast ionic conductor with high potential platform and thermal stability [14-16], which is expected to improve electrochemical performances of LFP. Previous studies [17-20] have shown that $x \mathrm{LFP} \cdot y \mathrm{LVP} / \mathrm{C}$ has better specific capacity, cyclic stability and rate capability than pristine $\mathrm{LiFePO}_{4} / \mathrm{C}$ (LFP/C). It is generally attributed to the mutual doping of $\mathrm{V}$ and $\mathrm{Fe}$ as well as synergistical effect of LFP and LVP phases, so as to improve the electric conductivity and $\mathrm{Li}^{+}$diffusion of $x \mathrm{LFP} \cdot y \mathrm{LVP} / \mathrm{C}$. Although several authors [21-24] have researched $\mathrm{LiFePO}_{4} \cdot \mathrm{Li}_{3} \mathrm{~V}_{2^{-}}$ $\left(\mathrm{PO}_{4}\right)_{3} / \mathrm{C}$ (LFP.LVP/C), the investigations are mainly focused on its electrochemical properties until now. To the best of our knowledge, few papers have discussed the magnetic performances of LFP.LVP/C. Nevertheless, magnetic properties are extremely sensitive to crystal imperfections and impurities which may indirectly affect

${ }^{1}$ School of Materials and Energy, Guangdong University of Technology, Guangzhou 510006, China

${ }^{2}$ Institute for Superconducting \& Electronic Materials, Australian Institute for Innovative Materials, University of Wollongong, Wollongong 2522, Australia

* Corresponding authors (emails: zhicong@gdut.edu.cn (Shi Z); shulei@uow.edu.au (Chou S)) 
electrochemical performances. Therefore, magnetic properties of LFP.LVP/C deserve to be highlighted further. Moreover, the complex crystal structure of LFP.LVP/C has posed a characterization challenge not solved by any single technique, requiring the combination of several characterization techniques.

In order to inhibit agglomeration of nanoparticles during heat drying, a sol-gel method combining with freeze-drying was introduced to synthesize LFP/C and LFP.LVP/C in this research. Our focus is on the details of their magnetic and electrochemical properties and then the comprehensive reasons for enhanced electrochemical properties of LFP.LVP/C composite. The results in this paper are believed to arouse wide interests in further research on the relationships between magnetism and electrochemistry of cathode materials.

\section{EXPERIMENTAL SECTION}

\section{Material synthesis}

LFP.LVP/C was synthesized by an improved sol-gel method. Raw materials $\mathrm{C}_{2} \mathrm{H}_{7} \mathrm{LiO}_{4}, \mathrm{FeCl}_{2} \cdot 4 \mathrm{H}_{2} \mathrm{O}, \mathrm{NH}_{4} \mathrm{H}_{2}$ $\mathrm{PO}_{4}$ and $\mathrm{C}_{6} \mathrm{H}_{8} \mathrm{O}_{7} \cdot \mathrm{H}_{2} \mathrm{O}$ with the molar ratio of 4:1:4:3 were separately dissolved in $100 \mathrm{~mL}$ deionized water. After dropping ferrous chloride solution into citric acid solution with strongly stirring, stoichiometric $\mathrm{NH}_{4} \mathrm{VO}_{3}$ was put into the mixed solution under continuous stirring to get a clear dark green solution. Then $\mathrm{NH}_{4} \mathrm{H}_{2} \mathrm{PO}_{4}$ and $\mathrm{LiOH} \cdot \mathrm{H}_{2} \mathrm{O}$ were added to the above solution in turn with magnetic stirring at $80^{\circ} \mathrm{C}$ until a black wet gel was formed. The wet gel was frozen in liquid nitrogen and freeze-dried more than $7 \mathrm{~d}$, then ball milled and calcined at $350^{\circ} \mathrm{C}$ for $5 \mathrm{~h}$ in flowing argon. Cooled down to room temperature slowly, the precursor was ball milled and sintered again at $750^{\circ} \mathrm{C}$ for $10 \mathrm{~h}$ in argon atmosphere to yield black LFP.LVP/C composite. For comparison, a LFP/C sample was prepared via the same procedure but without $\mathrm{NH}_{4} \mathrm{VO}_{3}$.

\section{Material characterizations}

The crystallinity and structure were characterized by Xray diffraction (XRD, Rigaku D/max-RB, Japan) with Co $\mathrm{Ka}$ radiation. A CS-8810C high-frequency infrared Carbon and sulfur analyzer (Wuxi, China) was used to confirm the carbon content. Raman spectra were obtained by a VG ESCALab250 spectrometer with monochromatic $\mathrm{Al} \mathrm{Ka}$ radiation and a HORIBA LabRAM HR with $633 \mathrm{~nm}$ He-Ne laser excitation. The surface morphology was observed using scanning electron microscopy (SEM, Hitachi, S-4800, Japan) and high-resolution scanning transmission electron microscopy (HRTEM, JEM-2010(HR), Japan). Magnetic tests (magnetization and susceptibility) were carried out with an automated magnetometer (MPMS-5S from Quantum Design) equipped with an ultra-sensitive SQUID within 4-300 K.

\section{Electrochemical measurements}

Electrochemical characteristics were investigated using CR2032 coin cells assembled in an argon-filled glove box. The cathode consisted of the as-synthesized powder, acetylene black and polyvinylidene fluoride binder in a weight ratio of 85:10:5. And the electrode loadings were in the range of $1.5-1.7 \mathrm{mg} \mathrm{cm}^{-2}$ on aluminum foil disks of $14 \mathrm{~mm}$ in diameter. A metallic lithium foil was used as the counter and reference electrode. The electrolyte was $1 \mathrm{~mol} \mathrm{~L}^{-1} \mathrm{LiPF}_{6}$ dissolved in ethylene carbonate (EC)diethyl carbonate (DEC)-dimethyl carbonate (DMC) (1:1:1 in volume). Galvanostatic charge-discharge tests were performed on a CT2001A battery testing system (Shenzhen, NEWARE, China) between 2.5-4.2 V (vs. $\mathrm{Li}^{+} /$ $\mathrm{Li})$. The measurements of cyclic voltammograms (CV) and electrochemical impedance spectroscopy (EIS) were conducted on a CHI660E electrochemical workstation (CHENHUA, China). CV curves were recorded in a potential window of $2.5-4.3 \mathrm{~V}\left(v s . \mathrm{Li}^{+} / \mathrm{Li}\right)$ at scan rates of 0.2 to $0.5 \mathrm{mV} \mathrm{s}^{-1}$. EIS experiments were performed within the frequency range of $1-10^{5} \mathrm{~Hz}$.

\section{RESULTS AND DISCUSSION}

The XRD and Rietveld refinement results of LFP/C and LFP.LVP/C are illustrated in Fig. 1. From Fig. 1a, it can be seen that all diffraction peaks of LFP/C are indexed as an olivine phase with orthorhombic structure (ICSD \#72545). While the LFP.LVP/C composite consists of both olivine $\mathrm{LiFePO}_{4}$ (ICSD \#72545) and monoclinic $\mathrm{Li}_{3}-$ $\mathrm{V}_{2}\left(\mathrm{PO}_{4}\right)_{3}$ (ICSD \#161335) phases without any other impurity. The Rietveld refinement results (Fig. 1b, c) further confirm that these samples are well crystallized. The weight fractions of LFP and LVP in LFP.LVP/C are 28.8 $(0.3) \%$ and $71.2(0.5) \%$, respectively, basically agreeing with theoretical values. Fig. 1d shows that diffraction peaks (for example (011) and (400) lattice planes) of LFP in LFP.LVP/C shift to low diffraction angles in comparison with those of pristine LFP/C, indicating the enlarged cell volume. The unit cell lattice parameters are calculated and listed in Table 1. The lattices of LFP in LFP.LVP/C are expanded in all dimensions agreeing with those reported in literatures $[21,23]$. The LVP phase gives the main contribution to it because the cell volume of LVP is nearly triple than that of LFP. In addition, no carbon 

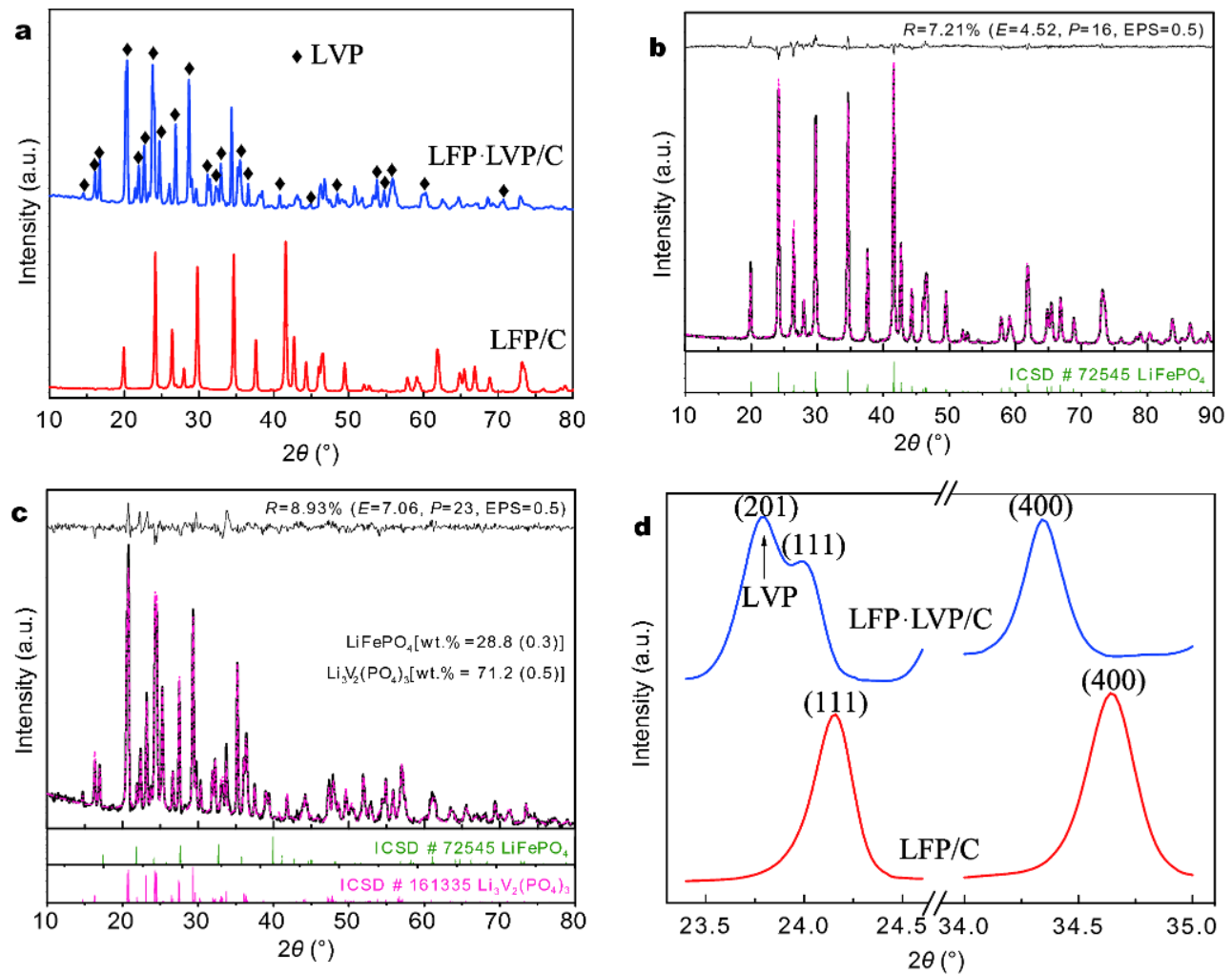

Figure 1 XRD (a) and Rietveld refinement results of LFP/C (b) and LFP.LVP/C (c), partial zoom of XRD diagrams (d).

Table 1 Refined unit-cell parameters $(a, b, c$ : three lengths of unit cell; $V$ : volume of unit cell, $R$ : R-factor) for LFP/C and LFP.LVP/C

\begin{tabular}{cccccccc}
\hline Samples & \multirow{2}{*}{$a(\AA)$} & $b(\AA)$ & $c(\AA)$ & $V\left(\AA^{3}\right)$ & $\begin{array}{c}\text { Measured phase content } \\
(\text { wt.\%) }\end{array}$ & $\begin{array}{c}\text { Theoretical phase content } \\
\text { (wt.\%) }\end{array}$ & $R(\%)$ \\
\hline LFP/C & $10.3280(2)$ & $6.0080(1)$ & $4.6951(1)$ & 291.3 & - & - & 7.21 \\
LFP in LFP.LVP/C & $10.3995(0)$ & $6.0760(6)$ & $4.7281(4)$ & 298.8 & $28.8(0.3)$ & 27.9 & 72.1 \\
LVP in LFP.LVP/C & $8.5324(9)$ & $8.5900(5)$ & $11.9633(6)$ & 876.8 & $71.2(0.5)$ & 8.93 \\
\hline
\end{tabular}

diffraction peaks have been detected through XRD tests. However, the contents of residual carbon in LFP/C and LFP.LVP/C are about 4.68 wt.\%, and 4.54 wt. $\%$, respectively. The residual carbon can also be identified by Raman spectra in Fig. 2. From Fig. 2a, b, the obvious Dband (disorder band) and G-band (graphite band) can be observed for both LFP/C and LFP.LVP/C $[25,26]$ and the corresponding peak intensity ratios $\left(I_{\mathrm{G}} / I_{\mathrm{D}}\right)$ are 1.15 and 1.27 , respectively. Only some weak peaks of $\mathrm{PO}_{4}{ }^{3-}$ can be found in two Raman spectra. These indicate that both samples were coated with uniform high-ordering carbon on the surfaces, inhibiting grain growth and forming excellent conductive network among the particles.

SEM images of LFP/C and LFP.LVP/C are compared in Fig. 3. It is obvious that both samples have homogenous particle size distribution, as shown in Fig. 3a, c. From Fig. $3 \mathrm{~b}$, we can see that LFP/C displays more or less rod shapes with about $200 \mathrm{~nm}$ in length and $150 \mathrm{~nm}$ in width and includes some large particles. However, the main particle shapes of LFP.LVP/C in Fig. 3d are quasi-spherical. The diameters range from about 50 to $120 \mathrm{~nm}$ with only a few large ones. Such particle size distribution is good for contact among particles and tap density of LFP.LVP/C. TEM image (Fig. 3e) illustrates that this composite is mainly composed of nanoparticles with different diameters consistent with Fig. 3d. In Fig. 3f, a uniform amorphous carbon layer with $2 \mathrm{~nm}$ in thickness is coated on the surface, in good agreement with Raman results.

Fig. 4 displays the isothermal plots of magnetic moments versus applied magnetic fields and the temperature dependences of reverse magnetic susceptibilities $\left(\chi^{-1}=\mathrm{H} /\right.$ M) for LFP/C and LFP.LVP/C, respectively. In Fig. 4a, non-linear behaviors at low-magnetic fields and linear 

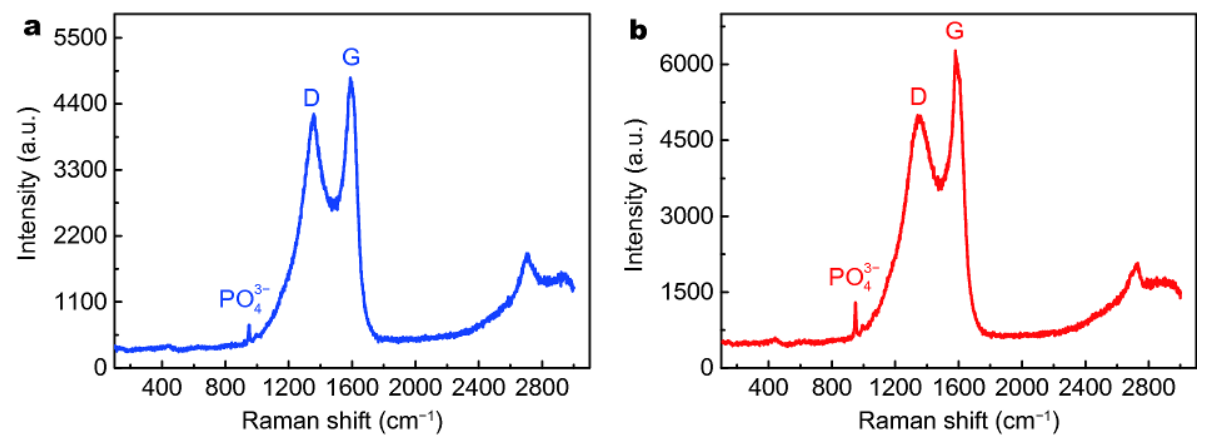

Figure 2 Raman spectra of LFP/C (a) and LFP.LVP/C (b).
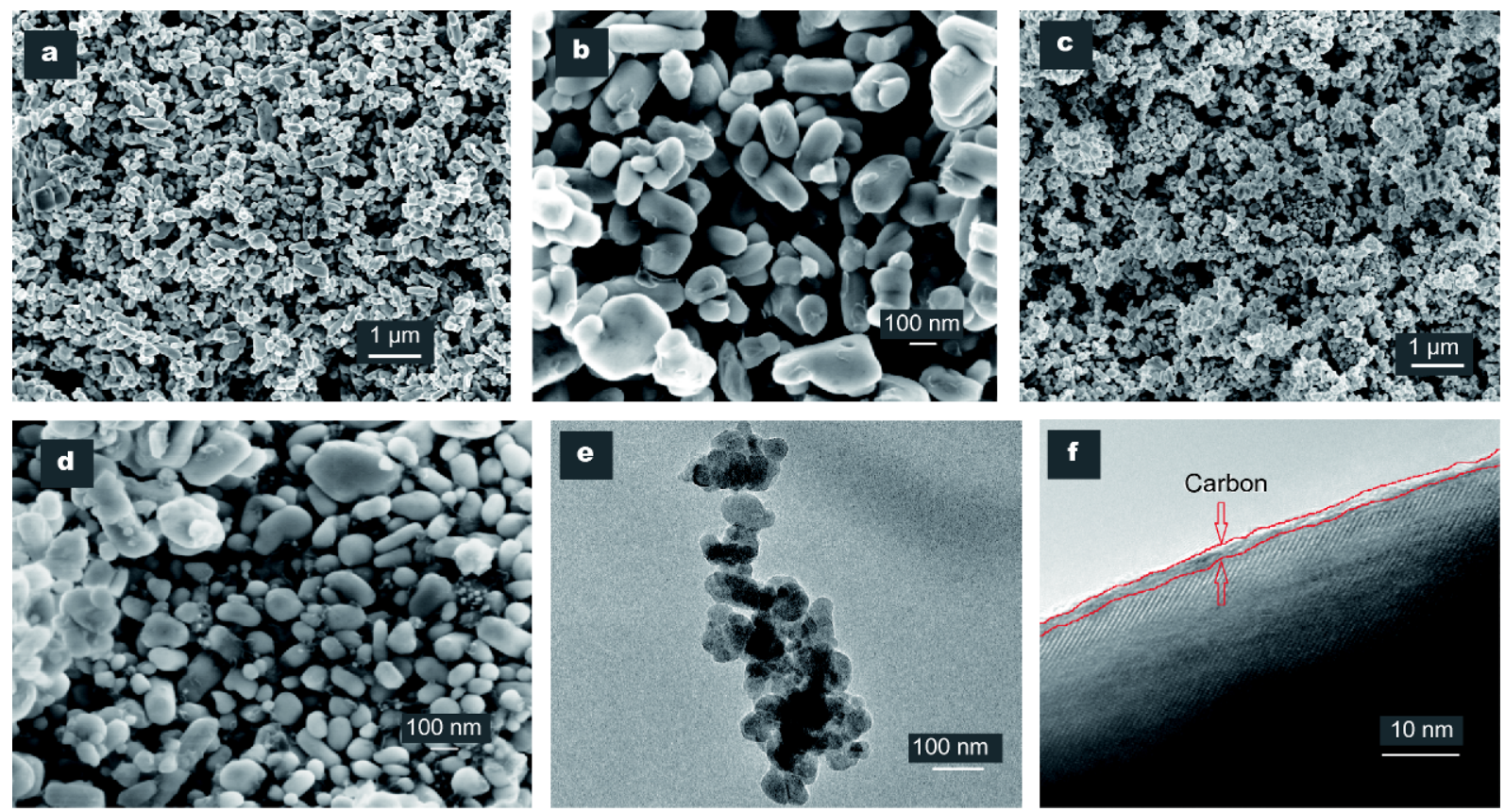

Figure 3 SEM images of LFP/C ( $a$ and $b$ ) and LFP.LVP/C (c and d); TEM (e) and HRTEM (f) of LFP.LVP/C.

variations at high-magnetic fields in $M(H, T)$ curves are observed even at room temperature $(300 \mathrm{~K})$. Moreover, all linear portions of the magnetization curves extrapolate to about the same magnetization (called $M_{0}$ ). There is only a peak of magnetic susceptibility at $T=52 \mathrm{~K}\left(T_{\mathrm{N}}\right.$, Néel temperature of pure crystallized LFP) in $\chi^{-1}(T)$ plot, which refers to the transition temperature from antiferromagnetic ordering to paramagnetic range for LFP/C $[27,28]$. A typical Curie-Weiss law behavior is then followed above $T_{\mathrm{N}}$. Therefore, the impurities included in LFP/C should be ferromagnetic and their magnetic ordering temperatures are much higher than room temperature, such as $\gamma-\mathrm{Fe}_{2} \mathrm{O}_{3}$ [29-31]. Supposing all impurities are $\gamma-\mathrm{Fe}_{2} \mathrm{O}_{3}$ phase in the form of small clusters dispersed in LFP/C, the total percent can be determined by formula $M_{0}=N n \mu(H, T)$ [29]. So the calculated fraction of impurities in LFP/C is $x=0.24$ wt.\%.

For LFP.LVP/C, the magnetic properties are obviously different with those of LFP/C (Fig. 4b). Firstly, $M(H, T)$ curves present non-linear behaviors at low-magnetic fields but with different curvatures. Secondly, the antiferromagnetism of LFP/C at low-magnetic fields in $\chi^{-1}(T)$ curve vanishes. Thirdly, the $\chi^{-1}(T)$ curve is divided into three parts with changed slopes by two transition temperatures located around 50 and $240 \mathrm{~K}$, respectively. Only above $240 \mathrm{~K}$, the $\chi^{-1}(T)$ curve of LFP.LVP/C obeys the Curie-Weiss law. The above differences are probably caused by following reasons. The first of all is the influ- 

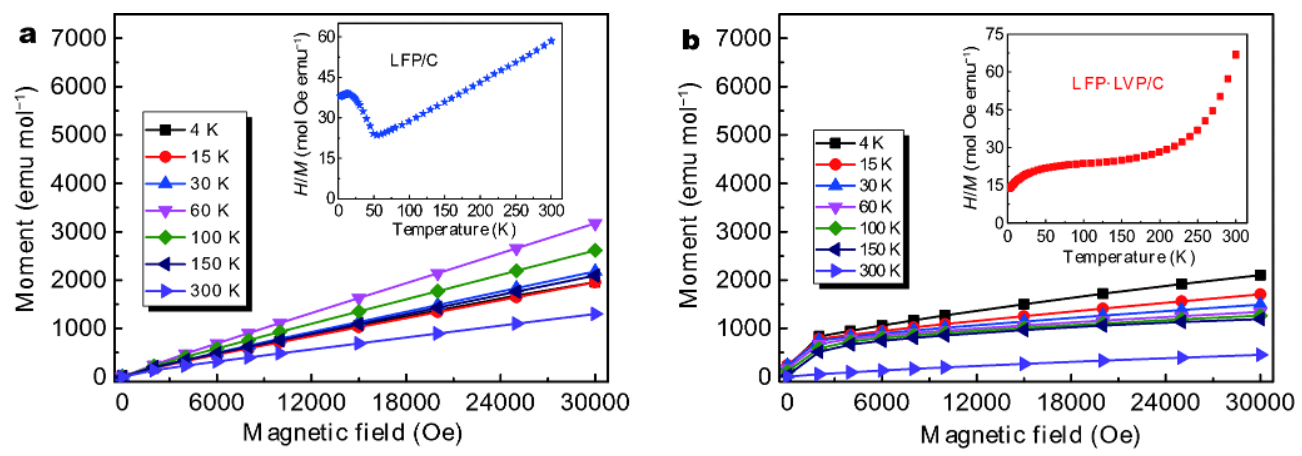

Figure 4 Magnetization curves of LFP/C (a) and LFP.LVP/C (b), the insets are temperature dependences of the reciprocal of magnetic susceptibilities of LFP/C and LFP.LVP/C, respectively.

ence of LVP second phase existing in LFP.LVP/C, which has been reported with paramagnetism [32-34]. Then the impurity included in LFP.LVP/C also plays a vital role. The main impurity comprised in LFP.LVP/C is most likely $\mathrm{Fe}_{2} \mathrm{P}$, because it is a ferromagnet with Curie temperature of $220-265 \mathrm{~K}$ reported in previous studies $[28,35]$. The deduced percent of $\mathrm{Fe}_{2} \mathrm{P}$ through $M_{0}=N n \mu$ $(H, T)$ is $0.44 \mathrm{wt} . \% . \mathrm{Fe}_{2} \mathrm{P}$ nanoparticles stuck on particles of LFP.LVP/C have been proved to be very conducive to electric conductivity $[29,36]$. Finally, the changed microstructure of LFP.LVP/C caused by mutual doping of iron and vanadium ions is another reason for different magnetic properties between LFP/C and LFP.LVP/C. Therefore, the significantly changed magnetic characteristics of LFP.LVP/C may indirectly affect the electrochemical performances of LFP.LVP/C applied as a cathode material for LIB. Magnetic results are inconsistent with former XRD results probably because the contents of impurities are below the threshold of XRD.

Fig. 5 shows the first and $100^{\text {th }}$ charge-discharge curves and cycling performances of LFP/C and LFP.LVP/C. LFP.LVP/C contains four potential plateaus corresponding to LFP and LVP respectively and possesses higher discharge midpoint voltages compared with LFP/C (Fig. 5a-d). Fig. 5e, f demonstrate that LFP/C exhibits a higher initial discharge capacity of $149.3 \mathrm{~mA} \mathrm{~h} \mathrm{~g}^{-1}$ than LFP. LVP/C (143.8 $\left.\mathrm{mA} \mathrm{h} \mathrm{g}^{-1}\right)$ at $0.2 \mathrm{C}$. However, LFP.LVP/C displays excellent rate capabilities with increased current density. At 1, 2 and 5 C, LFP.LVP/C provides the first specific capacities of $142.0,136.4$ and $130.0 \mathrm{~mA} \mathrm{~h} \mathrm{~g}^{-1}$, whereas LFP/C only shows 139.2, 131.8 and 123.3 $\mathrm{mA} \mathrm{h} \mathrm{g}{ }^{-1}$ respectively. And the discharge capacities of LFP.LVP/C have peaks at around the $10^{\text {th }}$ cycles due to activation process. LFP.LVP/C possesses capacity retentions of $99.2 \%, 99.0 \%, 98.4 \%$ and $98.3 \%$ (compared with the highest capacities not the first capacities) after 100 cycles at 0.2-5 $\mathrm{C}$ rates respectively, remarkably higher than LFP/C (98.4\%, 95.3\%, 92.9\% and 89.6\%). The electrochemical properties of LFP.LVP/C are also better than those in previous publications [21-23].

The EIS diagrams of LFP/C and LFP.LVP/C are given in Fig. 6. Fig. 6a shows that both diagrams consist of depressed semicircles and sloping lines before cycling. The depressed semicircles at high-middle frequencies represent the charge-transfer impedances of electrochemical reaction in the double-layer of electrode surface, and the slope lines at low frequencies are related to the diffusion-controlled Warburg impedances. Intersections of Nyquist plots with $Z^{\prime}$ real axis refer to the Ohmic resistance. While two depressed semicircles are observed at high-middle frequencies after 100 cycles in Fig. 6b, which correspond to the impedances of solid electrolyte interface (SEI) film and charge transfer, respectively [37]. Positive effect of SEI film on cyclic ability has been reported $[38,39]$. As can be seen, whether before or after charge/discharge, LFP.LVP/C presents smaller chargetransfer impedances than LFP/C, which benefits the improvement of electrochemical property for LFP.LVP/C.

The CV curves of LFP/C and LFP.LVP/C are provided in Fig. 7a, b. As shown in Fig. 7a, b, both LFP/C and LFP.LVP/C display well symmetric redox peaks at all scan rates. Four pairs of redox peaks for LFP.LVP/C match with those of LFP and LVP, respectively. The smaller potential differences between redox peaks of LFP in LFP.LVP/C $(0.09,0.11,0.12$ and $0.13 \mathrm{~V})$ at scan rates of $0.2-0.5 \mathrm{mV} \mathrm{s}^{-1}$ indicate the better electrochemical reversibility comparing with those of pristine LFP/C (0.21, $0.24,0.27$ and $0.29 \mathrm{~V})$. The sluggish kinetic lithium diffusion would be the main factor for relatively small redox peaks of LFP in LFP.LVP/C. According to CV results, $\mathrm{Li}^{+}$ diffusion coefficients $(D)$ around redox peaks can be calculated and the detailed calculation process consults 

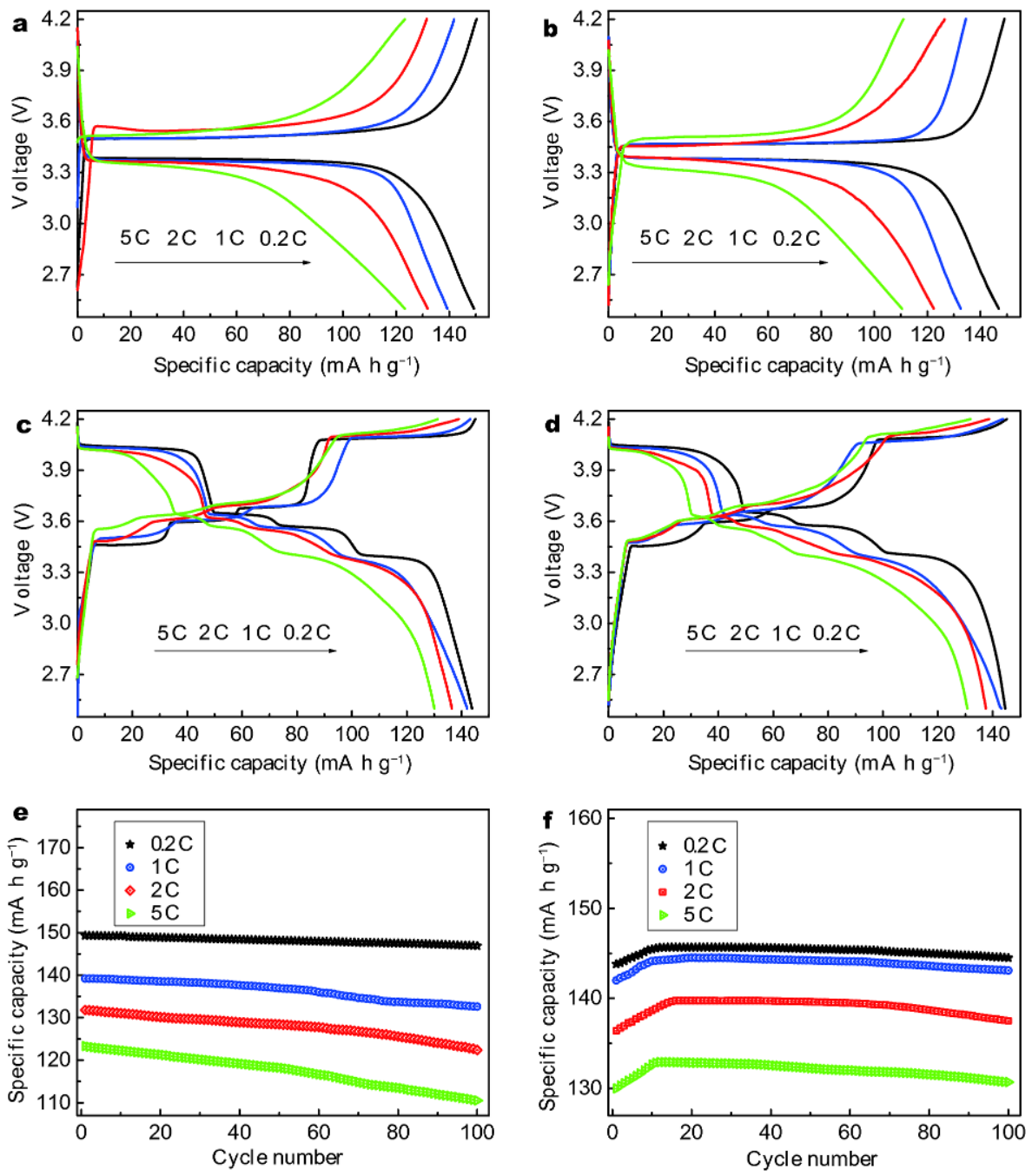

Figure 5 First and $100^{\text {th }}$ charge-discharge curves of LFP/C ( $a$ and $b$ ) and LFP.LVP/C (c and d); cycle performances of LFP/C (e) and LFP.LVP/C (f).
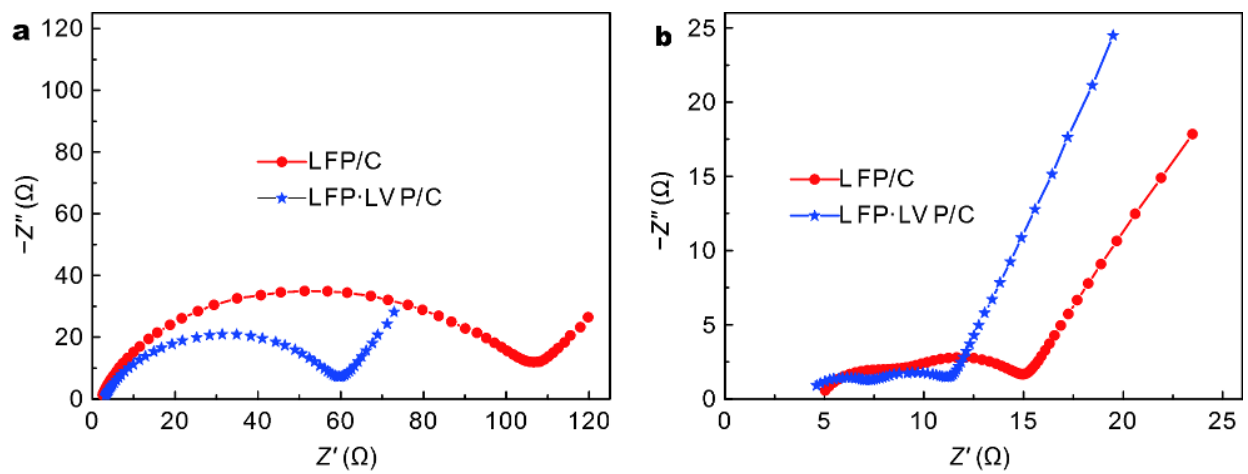

Figure 6 Nyquist plots of LFP/C and LFP.LVP/C at open circuit potential before charge-discharge tests (a) and after 100 cycles to the cut-off voltage of $2.5 \mathrm{~V}$ at $1 \mathrm{C}$ rate (b).

the former literature [32]. The linear fittings of $I_{\mathrm{p}} v s . v^{1 / 2}$ are illustrated in Fig. 7c, $\mathrm{d}$ and the calculated $D$ results are listed in Table 2. $D$ values of LFP in LFP.LVP/C are much larger than those of pristine LFP/C, especially in discharge process. Meanwhile, $D$ values of LVP in LFP.LVP/ $\mathrm{C}$ also increase compared with those of LVP/C in Ref. 

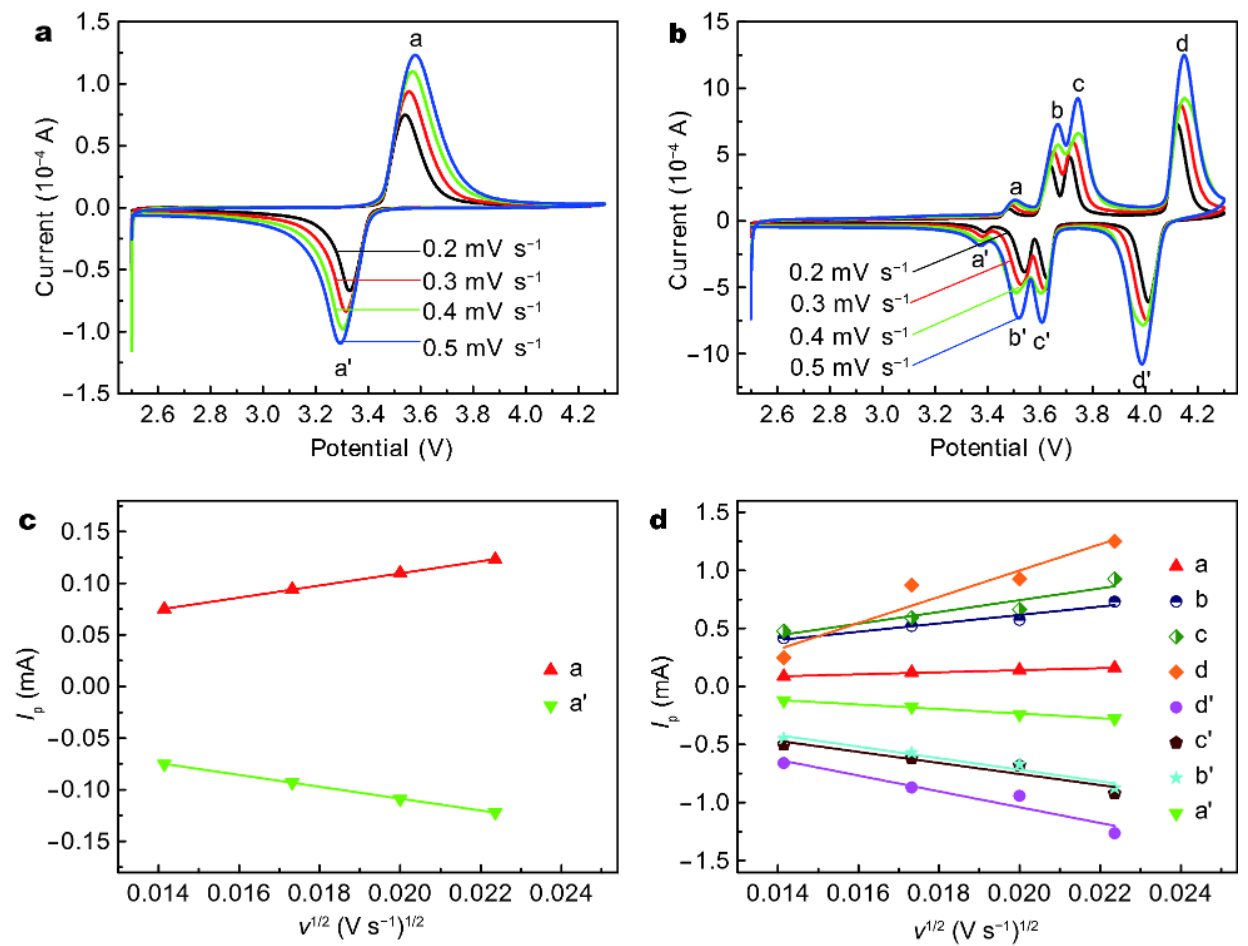

Figure $7 \mathrm{CV}$ curves of LFP/C (a) and LFP.LVP/C (b) at varied scan rates; linear fittings of $I_{\mathrm{p}} v s . v^{1 / 2}$ of LFP/C (c) and LFP.LVP/C (d) corresponding to different redox peaks.

Table 2 Values of calculated $D\left(\mathrm{~cm}^{2} \mathrm{~s}^{-1}\right)$

\begin{tabular}{ccccccccc}
\hline Peaks & $\mathrm{a}$ & $\mathrm{b}$ & $\mathrm{c}$ & $\mathrm{d}$ & $\mathrm{a}^{\prime}$ & $\mathrm{b}^{\prime}$ & $\mathrm{c}^{\prime}$ & $\mathrm{d}^{\prime}$ \\
\hline LFP/C & $1.62 \times 10^{-12}$ & - & - & - & $1.56 \times 10^{-12}$ & - & - & - \\
LFP in LFP.LVP/C & $5.31 \times 10^{-12}$ & - & - & - & $2.02 \times 10^{-11}$ & - & - \\
LVP in LFP.LVP/C & - & $6.32 \times 10^{-11}$ & $1.37 \times 10^{-10}$ & $8.67 \times 10^{-10}$ & - & $1.57 \times 10^{-10}$ & $5.29 \times 10^{-10}$ & $2.38 \times 10^{-10}$ \\
LVP/C [32] & - & $2.34 \times 10^{-11}$ & $5.66 \times 10^{-11}$ & $8.62 \times 10^{-11}$ & - & $1.04 \times 10^{-10}$ & $1.02 \times 10^{-10}$ & $2.04 \times 10^{-10}$ \\
\hline
\end{tabular}

[32]. Fast $\mathrm{Li}^{+}$diffusion helps to enhance electrochemical performances of LFP.LVP/C.

\section{CONCLUSIONS}

$\mathrm{LiFePO} \cdot \mathrm{Li}_{3} \mathrm{~V}_{2}\left(\mathrm{PO}_{4}\right)_{3} / \mathrm{C}$ composite has been successfully synthesized by a sol-gel method with freeze-drying. The composite is well crystallized with two homogeneous phases of $\mathrm{LiFePO}_{4}$ and $\mathrm{Li}_{3} \mathrm{~V}_{2}\left(\mathrm{PO}_{4}\right)_{3}$. And some $\mathrm{V}^{3+}$ and $\mathrm{Fe}^{2+}$ ions are doped into lattices of $\mathrm{LiFePO}_{4}$ and $\mathrm{Li}_{3} \mathrm{~V}_{2^{-}}$ $\left(\mathrm{PO}_{4}\right)_{3}$ respectively, leading to lattice changes and defects. The different magnetic properties between $\mathrm{LiFePO}_{4}$. $\mathrm{Li}_{3} \mathrm{~V}_{2}\left(\mathrm{PO}_{4}\right)_{3} / \mathrm{C}$ and $\mathrm{LiFePO}_{4} / \mathrm{C}$ and tiny impurities are confirmed by magnetic tests. The initial discharge capacities of $\mathrm{LiFePO}_{4} \cdot \mathrm{Li}_{3} \mathrm{~V}_{2}\left(\mathrm{PO}_{4}\right)_{3} / \mathrm{C}$ with high discharge plateaus are $142.0,136.4$ and $130.0 \mathrm{~mA} \mathrm{~h} \mathrm{~g}^{-1}$ and the capacity losses are less than $2 \%$ after 100 cycles at 1,2 and
$5 \mathrm{C}$ respectively, significantly higher than those of LiFe$\mathrm{PO}_{4} / \mathrm{C}$. The improvements are due to the mutual doping of vanadium and iron ions and synergistic effect of $\mathrm{LiFePO}_{4}$ and $\mathrm{Li}_{3} \mathrm{~V}_{2}\left(\mathrm{PO}_{4}\right)_{3}$ phases in combination with the existence of high-ordering carbon and $\mathrm{Fe}_{2} \mathrm{P}$ impurity in $\mathrm{LiFePO}_{4} \cdot \mathrm{Li}_{3} \mathrm{~V}_{2}\left(\mathrm{PO}_{4}\right)_{3} / \mathrm{C}$.

\section{Received 11 July 2017; accepted 11 September 2017;} published online 27 October 2017

1 Fan SS, Zhong H, Yu HT, et al. Hollow and hierarchical $\mathrm{Na}_{2} \mathrm{Li}_{2}-$ $\mathrm{Ti}_{6} \mathrm{O}_{14}$ microspheres with high electrochemical performance as anode material for lithium-ion battery. Sci China Mater, 2017, 60: 427-437

2 Wang $\mathrm{L}, \mathrm{Hu} \mathrm{Z}$, Zhao K, et al. Hollow spherical $\mathrm{LiNi}_{0.5} \mathrm{Mn}_{1.5} \mathrm{O}_{4}$ built from polyhedra with high-rate performance via carbon nanotube modification. Sci China Mater, 2016, 59: 95-103

$3 \mathrm{Tu}$ X, Zhou Y, Tian X, et al. Monodisperse $\mathrm{LiFePO}_{4}$ microspheres 
embedded with well-dispersed nitrogen-doped carbon nanotubes as high-performance positive electrode material for lithium-ion batteries. Electrochim Acta, 2016, 222: 64-73

4 Zhao JW, Zhao SX, Wu X, et al. Double role of silicon in improving the rate performance of $\mathrm{LiFePO}_{4}$ cathode materials. J Alloys Compd, 2017, 699: 849-855

5 Ren W, Wang K, Yang J, et al. Soft-contact conductive carbon enabling depolarization of $\mathrm{LiFePO}_{4}$ cathodes to enhance both capacity and rate performances of lithium ion batteries. J Power Sources, 2016, 331: 232-239

$6 \mathrm{Xu} \mathrm{Y,} \mathrm{Mao} \mathrm{J.} \mathrm{Improve} \mathrm{electrochemical} \mathrm{performance} \mathrm{of} \mathrm{LiFePO}_{4} / \mathrm{C}$ cathode by coating $\mathrm{Ti}_{2} \mathrm{O}_{3}$ through a facile route. Ionics, 2015, 21: 3159-3167

7 Tian X, Zhou Y, Tu X, et al. Well-dispersed $\mathrm{LiFePO}_{4}$ nanoparticles anchored on a three-dimensional graphene aerogel as high-performance positive electrode materials for lithium-ion batteries. J Power Sources, 2017, 340: 40-50

8 Li W, Zeng L, Wu Y, et al. Nanostructured electrode materials for lithium-ion and sodium-ion batteries via electrospinning. Sci China Mater, 2016, 59: 287-321

9 Zheng F, Yang C, Ji X, et al. Surfactants assisted synthesis and electrochemical properties of nano- $\mathrm{LiFePO}_{4} / \mathrm{C}$ cathode materials for low temperature applications. J Power Sources, 2015, 288: 337344

10 Bao L, Li L, Xu G, et al. Olivine $\mathrm{LiFePO}_{4}$ nanocrystallites embedded in carbon-coating matrix for high power Li-ion batteries. Electrochim Acta, 2016, 222: 685-692

11 Zhao N, Li Y, Zhi X, et al. Effect of $\mathrm{Ce}^{3+}$ doping on the properties of $\mathrm{LiFePO}_{4}$ cathode material. J Rare Earths, 2016, 34: 174-180

12 Meng X, Han B, Wang Y, et al. Effects of samarium doping on the electrochemical performance of $\mathrm{LiFePO}_{4} / \mathrm{C}$ cathode material for lithium-ion batteries. Ceramics Int, 2016, 42: 2599-2604

13 Chen M, Shao LL, Yang HB, et al. Vanadium-doping of $\mathrm{LiFePO}_{4} /$ carbon composite cathode materials synthesized with organophosphorus source. Electrochim Acta, 2015, 167: 278-286

14 Zhang $\mathrm{X}$, Kühnel RS, $\mathrm{Hu} \mathrm{H}$, et al. Going nano with protic ionic liquids-The synthesis of carbon coated $\mathrm{Li}_{3} \mathrm{~V}_{2}\left(\mathrm{PO}_{4}\right)_{3}$ nanoparticles encapsulated in a carbon matrix for high power lithium-ion batteries. Nano Energy, 2015, 12: 207-214

15 Liang $\mathrm{S}, \mathrm{Hu}$ J, Zhang $\mathrm{Y}$, et al. Facile synthesis of sandwich-structured $\mathrm{Li}_{3} \mathrm{~V}_{2}\left(\mathrm{PO}_{4}\right)_{3} /$ carbon composite as cathodes for high performance lithium-ion batteries. J Alloys Compd, 2016, 683: 178-185

16 Yan H, Zhang G, Li Y. Synthesis and characterization of advanced $\mathrm{Li}_{3} \mathrm{~V}_{2}\left(\mathrm{PO}_{4}\right)_{3}$ nanocrystals@conducting polymer PEDOT for high energy lithium-ion batteries. Appl Surf Sci, 2017, 393: 30-36

17 Liang $\mathrm{S}$, Cao X, Wang $\mathrm{Y}$, et al. Uniform $8 \mathrm{LiFePO} \cdot \mathrm{Li}_{3} \mathrm{~V}_{2}\left(\mathrm{PO}_{4}\right)_{3} / \mathrm{C}$ nanoflakes for high-performance Li-ion batteries. Nano Energ, 2016, 22: 48-58

18 Zhang $\mathrm{X}$, Huang $\mathrm{M}$, Huang J, et al. Preparation and electrochemical performance of $7 \mathrm{LiFePO} \cdot 3 \mathrm{Li}_{3} \mathrm{~V}_{2}\left(\mathrm{PO}_{4}\right)_{3} / \mathrm{C}$. Mater Chem Phys, 2015, 167: 253-257

19 Zhong S, Wu L, Zheng J, et al. Preparation of high tap-density $9 \mathrm{LiFePO} \cdot \cdot \mathrm{Li}_{3} \mathrm{~V}_{2}\left(\mathrm{PO}_{4}\right)_{3} / \mathrm{C}$ composite cathode material by spray drying and post-calcining method. Powder Tech, 2012, 219: 45-48

20 Zhang B, Li H, Zhang J. High-rate electrode material $2 \mathrm{LiFePO}_{4}$. $\mathrm{Li}_{3} \mathrm{~V}_{2}\left(\mathrm{PO}_{4}\right)_{3} @$ carbon/graphene using the in situ grown $\mathrm{Fe}_{4}\left(\mathrm{VO}_{4}\right)_{4}$. $15 \mathrm{H}_{2} \mathrm{O}$ precursor on the surface of graphite oxide. RSC Adv, 2015, 5: 32191-32197

21 Yang G, Jiang CY, He XM, et al. Preparation of $\mathrm{Li}_{3} \mathrm{~V}_{2}\left(\mathrm{PO}_{4}\right)_{3} /$ $\mathrm{LiFePO}_{4}$ composite cathode material for lithium ion batteries. Io- nics, 2013, 19: 1247-1253

22 Jo J, Gim J, Song J, et al. One-pot pyro-synthesis of a high energy density $\mathrm{LiFePO}_{4}-\mathrm{Li}_{3} \mathrm{~V}_{2}\left(\mathrm{PO}_{4}\right)_{3}$ nanocomposite cathode for lithiumion battery applications. Ceramics Int, 2017, 43: 4288-4294

23 Guo Y, Huang Y, Jia D, et al. Preparation and electrochemical properties of high-capacity $\mathrm{LiFePO}_{4}-\mathrm{Li}_{3} \mathrm{~V}_{2}\left(\mathrm{PO}_{4}\right)_{3} / \mathrm{C}$ composite for lithium-ion batteries. J Power Sources, 2014, 246: 912-917

$24 \mathrm{He} \mathrm{W}$, Wei $\mathrm{C}$, Zhang $\mathrm{X}$, et al. $\mathrm{Li}_{3} \mathrm{~V}_{2}\left(\mathrm{PO}_{4}\right)_{3} / \mathrm{LiFePO}_{4}$ composite hollow microspheres for wide voltage lithium ion batteries. Electrochim Acta, 2016, 219: 682-692

25 An C, Liu X, Gao Z, et al. Filling and unfilling carbon capsules with transition metal oxide nanoparticles for Li-ion hybrid supercapacitors: towards hundred grade energy density. Sci China Mater, 2017, 60: 217-227

26 Yao L. Facile synthesis of $\mathrm{LiFePO}_{4} / \mathrm{C}$ with high tap-density as cathode for high performance lithium ion batteries. Int $\mathrm{J}$ Electrochem Sci, 2017, 12: 206-217

27 Shang W, Kong L, Ji X. Synthesis, characterization and electrochemical performances of $\mathrm{LiFePO}_{4} /$ graphene cathode material for high power lithium-ion batteries. Solid State Sci, 2014, 38: 79-84

28 Masrour R, Hlil EK, Obbade S, et al. Theoretical and experimental investigations of the structural, magnetic, electronic, and electrical properties of olivine $\mathrm{LiFePO}_{4}$. Solid State Ion, 2016, 289: 214-219

29 Zaghib K. Magnetic studies of phospho-olivine electrodes in relation with their electrochemical performance in Li-ion batteries. Solid State Ion, 2008, 179: 16-23

30 Brochu F, Guerfi A, Trottier J, et al. Structure and electrochemistry of scaling nano C-LiFePO ${ }_{4}$ synthesized by hydrothermal route: complexing agent effect. J Power Sources, 2012, 214: 1-6

31 Zaghib $\mathrm{K}$, Charest $\mathrm{P}$, Dontigny $\mathrm{M}$, et al. $\mathrm{LiFePO}_{4}$ : from molten ingot to nanoparticles with high-rate performance in Li-ion batteries. J Power Sources, 2010, 195: 8280-8288

32 Liu L, Lei $\mathrm{X}$, Tang $\mathrm{H}$, et al. Influences of La doping on magnetic and electrochemical properties of $\mathrm{Li}_{3} \mathrm{~V}_{2}\left(\mathrm{PO}_{4}\right)_{3} / \mathrm{C}$ cathode materials for lithium-ion batteries. Electrochim Acta, 2015, 151: 378-385

33 Liu L, Qiu Y, Mai Y, et al. Influences of neodymium doping on magnetic and electrochemical properties of $\mathrm{Li}_{3} \mathrm{~V}_{2}\left(\mathrm{PO}_{4}\right)_{3} / \mathrm{C}$ synthesized via a sol-gel method. J Power Sources, 2015, 295: 246-253

34 Zhang LL, Liang G, Peng G, et al. Significantly improved electrochemical performance in $\mathrm{Li}_{3} \mathrm{~V}_{2}\left(\mathrm{PO}_{4}\right)_{3} / \mathrm{C}$ promoted by $\mathrm{SiO}_{2}$ coating for lithium-ion batteries. J Phys Chem C, 2012, 116: 12401-12408

35 Salah AA, Mauger A, Julien CM, et al. Nano-sized impurity phases in relation to the mode of preparation of $\mathrm{LiFePO}_{4}$. Mater Sci EngB, 2006, 129: 232-244

36 Dhindsa KS, Kumar A, Nazri GA, et al. Enhanced electrochemical performance of $\mathrm{LiFePO}_{4} / \mathrm{C}$ nanocomposites due to in situ formation of $\mathrm{Fe}_{2} \mathrm{P}$ impurities. J Solid State Electrochem, 2016, 20: 22752282

37 Rui $\mathrm{XH}$, Jin $\mathrm{Y}$, Feng $\mathrm{XY}$, et al. A comparative study on the lowtemperature performance of $\mathrm{LiFePO}_{4} / \mathrm{C}$ and $\mathrm{Li}_{3} \mathrm{~V}_{2}\left(\mathrm{PO}_{4}\right)_{3} / \mathrm{C}$ cathodes for lithium-ion batteries. J Power Sources, 2011, 196: 21092114

38 Xu J, Xia Q, Chen F, et al. Facilely solving cathode/electrolyte interfacial issue for high-voltage lithium ion batteries by constructing an effective solid electrolyte interface film. Electrochim Acta, 2016, 191: 687-694

39 Yi T F, Han X, Yang S Y, et al. Enhanced electrochemical performance of Li-rich low-Co $\mathrm{Li}_{1.2} \mathrm{Mn}_{0.56} \mathrm{Ni}_{0.16} \mathrm{Co}_{0.08-x} \mathrm{Al}_{x} \mathrm{O}_{2}$ $(0 \leq x \leq 0.08)$ as cathode materials. Sci China Mater, 2016, 59: 618628 
Acknowledgements This work was supported by the National Natural Science Foundation of China (21673051), Guangdong Province Science \& Technology Bureau (2014A010106029, 2014B010106005 and 2016A010104015), Guangzhou Science \& Innovative Committee (201604030037), the Youth Foundation of Guangdong University of Technology (252151038), the link project of the National Natural Science Foundation of China and Guangdong Province (U1401246), and the Science and Technology Program of Guangzhou City of China (201508030018).
Author contributions Liu L designed the experiments and wrote the initial manuscript; Xiao $\mathrm{W}$ and Guo J performed the experiments with support from Liu L, Cui Y and Chen Y; Shi Z and Chou S guided the work. All authors contribute to analysis of the data and advice for the paper writing.

Conflict of interest The authors declare that they have no conflict of interest.

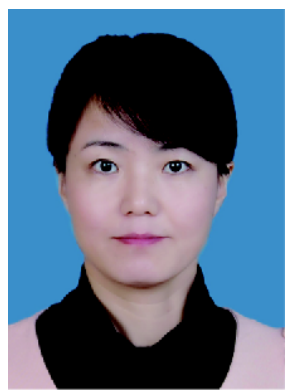

Liying Liu received her PhD degree in 2006 from Northeastern University. Then she joined Guangdong University of Technology as a lecturer until now. Meanwhile, she worked as a post-doctoral fellow in Mcnair Technology Co., Ltd. from 2008 to 2010, as a visiting fellow at University of Wollongong in Australia from 2016 to 2017. Her research focuses on energy storage materials for batteries.
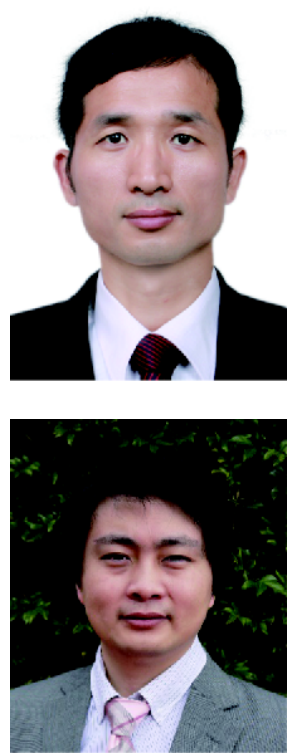

Zhicong Shi is a professor at Guangdong University of Technology, where he presently serves as the Head of Department of New Energy Materials and Devices and the Director of Guangdong Engineering Centre for New Energy Materials and Devices. He received his PhD in physical chemistry from Xiamen University in 2005. His current research interests include novel materials for batteries, supercapacitors and fuel cells.
ShuLei Chou is a senior research fellow in ISEM at University of Wollongong (UOW). He obtained his Bachelor (1999) and Master degree (2004) in Nankai University, China. His PhD degree was received from UOW with the best thesis award in 2010. His research has been focused on energy storage materials for battery applications, especially on novel composite materials, new binders and new electrolytes for $\mathrm{Li} / \mathrm{Na}$ batteries.

\section{冷冻干燥辅助溶胶-凝胶法制备纳米复合材料 $\mathrm{LiFePO}_{4} \cdot \mathrm{Li}_{3} \mathrm{~V}_{2}\left(\mathrm{PO}_{4}\right)_{3} / \mathrm{C}$ 及其磁学和电化学性能的研究}

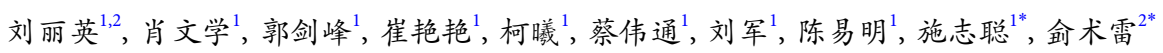

摘要 本文采用冷冻干燥与溶胶-凝胶相结合的方法制备了纳米复合材料 $\mathrm{LiFePO}_{4} \cdot \mathrm{Li}_{3} \mathrm{~V}_{2}\left(\mathrm{PO}_{4}\right)_{3} / \mathrm{C} . \mathrm{XRD}$ 结果表明该复合材料主要由橄榄石 型 $\mathrm{LiFePO}_{4}$ 和单斜晶系 $\mathrm{Li}_{3} \mathrm{~V}_{2}\left(\mathrm{PO}_{4}\right)_{3}$ 相组成, 同时包含少量的 $\mathrm{V}$ 掺杂 $\mathrm{LiFePO}_{4}$ 和 $\mathrm{Fe}$ 掺杂 $\mathrm{Li}_{3} \mathrm{~V}_{2}\left(\mathrm{PO}_{4}\right)_{3}$. 磁学测试结果表明, $\mathrm{LiFePO}_{4} \cdot \mathrm{Li}_{3} \mathrm{~V}_{2}\left(\mathrm{PO}_{4}\right)_{3} / \mathrm{C}$ 的磁学特性显著区别于 $\mathrm{LiFePO}_{4} / \mathrm{C}$, 并且痕量的铁磁性杂质和 $\mathrm{Fe}_{2} \mathrm{P}$ 杂质分别存在于 $\mathrm{LiFePO} \mathrm{P}_{4} / \mathrm{C}$ 和 $\mathrm{LiFePO}_{4} \cdot \mathrm{Li}_{3} \mathrm{~V}_{2}\left(\mathrm{PO}_{4}\right)_{3} / \mathrm{C}$ 中. $\mathrm{LiFePO}_{4} \cdot \mathrm{Li}_{3} \mathrm{~V}_{2}$ $\left(\mathrm{PO}_{4}\right)_{3} / \mathrm{C}$ 具有相对优良的循环稳定性, 尤其是在大倍率条件下. 在 $2 \mathrm{C}$ 和 $5 \mathrm{C}$ 时, 首次放电容量分别为 136.4 和 $130.0 \mathrm{~mA} \mathrm{~h} \mathrm{~g}$, 100 周循环后 保持率在 $98 \%$ 以, 优于 $\mathrm{LiFePO}_{4} / \mathrm{C}$ 的电化学性能. $\mathrm{LiFePO}_{4} \cdot \mathrm{Li}_{3} \mathrm{~V}_{2}\left(\mathrm{PO}_{4}\right)_{3} / \mathrm{C}$ 电化学性能的改善归因于 $\mathrm{V}^{3+}$ 和 $\mathrm{Fe}^{2+}$ 的相互掺杂, $\mathrm{LiFePO}_{4}$ 和 $\mathrm{Li}_{3} \mathrm{~V}_{2}{ }^{-}$ $\left(\mathrm{PO}_{4}\right)_{3}$ 相的优势互补, 残留的高有序碳以及导电性优异的 $\mathrm{Fe}_{2} \mathrm{P}$. 